\title{
Effect of Minor Nutrient Elements and Magnesium Upon the Growth, Development, and Yields of Plantains
}

\author{
E. Hernández Medina and M. A. Lugo López ${ }^{1}$
}

\section{INTRODUCTION}

Minor nutrients, in addition to secondary nutrients and the long-recognized major (NPK) elements, play very important roles in plant metabolism. The major elements are used by crops in relatively large amounts, while the socalled secondary and minor elements are used in rather small amounts. However, all are essential for normal plant growth. Secondary and minor elements are not currently used in crop fertilization in Puerto Rico. Perhaps, the use of iron sprays in pineapple fields is about the only exception.

This paper reports on experimental work under field conditions to evaluate the effect of soil and foliar applications of minor elements and magnesium, a secondary element, upon the growth and production of plantains. (Musa paradisiaca, L.)

\section{PREVIOUS WORK}

Research work with minor elements on our crops was initiated at the Agricultural Experiment Station of the University of Puerto Rico in the late 30's. Most of the work done at the beginning was with with pineapples. Schappelle $(10)^{2}$ reported that excess manganese and zinc tend to cause chlorosis in pineapple, due to the nonfunctioning of iron. However, with the addition of aluminum and boron, this chlorosis was controlled. He found that when copper was added at the rate of 2 p.p.m. a root fungus was controlled.

Under certain conditions, pineapple plants in Puerto Rico show severe manganese toxicity. Hopkins (6) stated that chlorosis developed by pineapple plants due to manganese toxicity can be controlled by correcting the $\mathrm{Fe} / \mathrm{Mn}$ ratio. In later work Ramirez-Silva (9) showed the importance of iron in controlling pineapple chlorosis due to high manganese, while Landrau and Samuels $(8)$ found that iron sprays and fritted trace elements were responsible for increasing yields of pineapple.

Experimental data obtained by Bonnet (1) showed that there was an in-

${ }^{1}$ Agronomist and Soil Scientist, respectively, Agricultural Experiment Station, Mayagüez Campus, University of Puerto Rico, Río Piedras, P.R.

2 Italic numbers in parentheses refer to Literature Cited, pp. 40. 
crease in yield of sugarcane associated with applications of iron, manganese, and copper in calcareous soils. Studies done with boron in Puerto Rico soils, using sunflower as the indicator plant, have indicated that Utuado loam, one of the tested soils, is deficient in this element. ${ }^{3}$

The research work with magnesium had been of a rather limited nature both with respect to crops and to soils studied. The first work with magnesium carried on by Schappelle in the early 40's indicated that small amounts of this nutrient tended to favor increased production of pineapple (10). In the work of Landrau and Samuels there was also a trend toward increases in yields of sweetpotatoes with magnesium applications $(7,8)$. The latest published work on magnesium by Hernández-Medina $(3,4,5)$ clearly demonstrates the outstanding beneficial effect of this nutrient ele-

TABLE 1.-Minor elements and magnesium applied to soil and foliage of plantains grown in Lares clay, Corozal, P.R.

\begin{tabular}{l|l|c|c}
\hline Nutrient supplied & \multicolumn{1}{|c|}{ Source } & $\begin{array}{c}\text { Soil } \\
\text { application }\end{array}$ & $\begin{array}{c}\text { Spray } \\
\text { application }\end{array}$ \\
\hline & Borax & Lb./acre & Lb./100 gal. \\
Boron & Copper sulfate & 50 & 2 \\
Copper & Zinc sulfate & 50 & 1 \\
Zinc & Chelated iron (FeEDTA) & 25 & 1 \\
Iron & Manganese sulfate & 50 & 2 \\
Manganese & Sodium molybdate & 25 & .5 \\
Molybdenum & Magnesium sulfate & 500 & 5 \\
Magnesium & (Epsom salt) & & \\
\hline
\end{tabular}

ment on pineapples and coffee yields. Caro-Costas et al. (2) have found similar response with magnesium on plantains. The potentialities of magnesium becoming an important nutrient element in the fertilization program of our crops of economic importance merits further studies.

\section{MATERIALS AND METHODS}

A field experiment was planned in the spring in a Lares clay soil at the Corozal Substation farm to determine the response of plantains to minor elements and magnesium when supplied to the soil or applied as sprays.

The experimental layout for a combined NPK and secondary minornutrients study followed a $4 \times 5$ nearly balanced rectangular lattice design with 20 treatments and 5 replications. Plots were $18 \times 18$ feet with 4 plants each. Planting holes were $18 \times 18 \times 8$ inches. Limestone was applied to all plots at the rate of $31 / 2$ tons to the acre so as to raise the soil $\mathrm{pH}$ to 6.0 . The

${ }^{3}$ Gaztambide de Urrutia, Socorro, files, Department of Agronomy and Soils. 
soil was treated with Aldrin ${ }^{4}$ at the rate of 1 gal. (25-percent concentrate) per 100 gallons of water per acre. Both limestone and Aldrin were worked into the topmost 4 to 6 inches of soil. Planting material of the Enano cultivar was used after selecting 400 suckers for uniformity as to size and weight.

The magnesium and minor-nutrient study included 10 treatments. Table 1 indicates the various fertilizer sources supplying a particular nutrient with rates used as soil or foliar treatments.

Hydrated lime was added to the spray solution to maintain the required $\mathrm{pH}$ control. NuFilm at the rate of 250 c.c. was used as a sticker and spreader.

All plots received NPK at the rate of 200 pounds of each major nutrient. The following schedule was followed in the plots requiring soil applications:

$1 / 3$ of the total nutrients applied in spring.

$1 / 3$ of the total nutrients applied in summer.

$1 / 3$ of the total nutrients applied in the fall.

For the spray treatments the following schedule was followed:

1st spray in the summer when plants were 3 months old.

2nd spray in the summer when plants were 4 months old.

$3 \mathrm{~d}$ spray in the fall when plants were 6 months old.

4th spray in the fall when plants were 7 months old.

5th spray in the fall when plants were 7 months old.

6 th spray in the fall when plants were 7 months old.

$\Lambda$ fter the third spray there were heavy rains; thus the 4th spray followed 6 days afterwards. The same situation occurred after the 5th spray, with the 6 th following after 2 weeks.

The following measurements were taken:

1. Height of plants when $\mathbf{5}$ to $\mathbf{1 0}$ months old as measured from the soil surface to the point where the top newest leaf formed an angle with the unrolled forthcoming leaf.

2. Trunk circumference at same ages was measured 12 inches from the soil surface.

3. Number of dry and green leaves counted at 5 and 10 months, respectively.

4. Number of suckers counted at 5 months.

5. Mean yields of fruit per acre.

6. Mean number of fruits per acre.

7. Mean number of hands per acre.

4 Trade names are used in this publication solely for the purpose of providing specific information. Mention of a trade name does not constitute a guarantee or endorsement by the U.S. Department of Agriculture or the Agricultural Experiment Station indicating superiority to other similar products not mentioned. 
All the data obtained were statistically analyzed and the least significant difference calculated for comparing the means of each treatment for the various growth, development, and yield criteria.

\section{RESULTS AND DISCUSSION}

Data on growth and development criteria are presented in table 2. Yield data are presented in table 3 . Results of correlation studies between growth

TABLE 2.-Effect of minor elements and magnesium on the growth and development of plantains

\begin{tabular}{|c|c|c|c|c|c|c|c|}
\hline \multirow{2}{*}{$\begin{array}{l}\text { Soil application } \\
\text { and Sprays }\end{array}$} & \multicolumn{2}{|c|}{$\begin{array}{l}\text { Plant height } \\
\text { at }-\end{array}$} & \multicolumn{2}{|c|}{$\begin{array}{c}\text { Stem cir- } \\
\text { cumference at- }\end{array}$} & \multirow{2}{*}{$\begin{array}{c}\text { Dry } \\
\text { leaves } \\
\text { at } \\
5 \text { months }\end{array}$} & \multirow{2}{*}{$\begin{array}{l}\text { Green } \\
\text { leaves } \\
\text { at } 10 \\
\text { months }\end{array}$} & \multirow{2}{*}{$\begin{array}{l}\text { Suckers } \\
\text { at } 5 \\
\text { months }\end{array}$} \\
\hline & $\begin{array}{c}5 \\
\text { months }\end{array}$ & $\begin{array}{c}10 \\
\text { months }\end{array}$ & $\underset{\text { months }}{5}$ & $\begin{array}{c}10 \\
\text { months }\end{array}$ & & & \\
\hline \multirow{2}{*}{\multicolumn{8}{|c|}{\begin{tabular}{l|l|l|l} 
& Inches & Inches & Inches
\end{tabular}}} \\
\hline & & & & & & & \\
\hline $\begin{array}{l}\text { Complete fertilizer (NPK, } \\
\text { minor elements and } \\
\text { magnesium) }\end{array}$ & 52.8 & 87.5 & 15.2 & 28.7 & 3 & 11 & 1.6 \\
\hline NPK only & 40.9 & 73.3 & 13.0 & 26.0 & 7 & 8 & .8 \\
\hline \multicolumn{8}{|l|}{ Foliar sprays: } \\
\hline $\begin{array}{l}\text { Complete fertilizer (as } \\
\text { above) }\end{array}$ & 42.3 & 82.4 & 13.2 & 28.4 & 5 & 10 & .8 \\
\hline Id. except $\mathrm{Mg}$ & 43.9 & 83.8 & 13.7 & 28.3 & 6 & 10 & 1.3 \\
\hline Id. except Fe & 41.4 & 77.8 & 13.0 & 26.9 & 6 & 9 & .8 \\
\hline Id. except Mn & 44.2 & 81.1 & 13.9 & 28.3 & 6 & 9 & 1.3 \\
\hline Id. except $B$ & 44.2 & 78.4 & 13.5 & 27.2 & 5 & 9 & 1.0 \\
\hline Id. except $\mathrm{Zn}$ & 38.6 & 71.2 & 12.3 & 25.8 & 6 & 8 & .4 \\
\hline Id. except $\mathrm{Cu}$ & 47.1 & 84.2 & 14.7 & 28.7 & 6 & 9 & 1.0 \\
\hline Id. except Mo & 39.4 & 78.3 & 12.7 & 27.2 & 6 & 10 & .8 \\
\hline \multicolumn{8}{|l|}{ L.S.D. at- } \\
\hline 5-percent level & 4.9 & 12.3 & 3.4 & 3.4 & 1 & 2 & .8 \\
\hline 1-percent level & 6.5 & 16.2 & 3.2 & 4.5 & 2 & 3 & 1.1 \\
\hline
\end{tabular}

and development criteria and plantain yields are presented in table 4.

As shown in table 2 the omission of secondary and minor elements from the fertilizer applied to the soil reduced significantly the growth and development of plantains as measured by plant height at 5 and 10 months. The differences in stem circumference were not significant. There were significant differences as to number of dry leaves, number of green leaves, and number of suckers.

Foliar sprays of complete fertilizer, as indicated in table 1, were not as effective as soil applications. No logical significant differences were measured 
when any of the elements were omitted from the nutrient spray, although the omission of $\mathrm{Zn}$ tended to produce the smallest plants (both as to height and circumference), the smallest number of green leaves at 10 months, and the smallest number of suckers at 5 months.

As shown in table 3 the omission of secondary and minor elements from the fertilizer mixture applied to the soil caused highly significant reductions in the yield of plantains grown in a Lares clay of the Corozal area. The three yield eriteria, namely, hundredweights of plantains per acre, number of fruits per acre, and number of hands per acre, were all significantly affected.

TABLE 3.-Effect of minor elements and magnesium on the yield of plantains

\begin{tabular}{l|c|c|c}
\hline \multicolumn{1}{c|}{ Treatment } & Mean yield per acre & Fruits per acre & Hands per acre \\
\cline { 2 - 3 } & Hundredweights & Number & Number \\
Soil application: & 166.9 & 26,028 & \\
$\quad \begin{array}{l}\text { Complete fertilizer (NPK, } \\
\quad \text { minor elements and mag. }\end{array}$ & & & 4,141 \\
$\quad$ nesium) & 107.2 & 18,930 & \\
NPK only & & & 3,227 \\
Foliar sprays: & 147.6 & 25,114 & 3,549 \\
Complete fertilizer (as above) & 137.1 & 22,210 & 3,603 \\
Id. except Mg & 111.8 & 21,081 & 3,388 \\
Id. except Fe & 126.7 & 21,619 & 3,496 \\
Id. except Mn & 124.9 & 21,135 & 3,711 \\
Id. except B & 109.8 & 18,446 & 3,280 \\
Id. except Zn & 141.1 & 23,447 & 3,711 \\
Id. except Cu & 134.4 & 21,511 & 3,711 \\
Id. except Mo & & & \\
\hline L.S.D. at- & 32.2 & 3,173 & 376 \\
5-percent level & 42.9 & 4,248 & 484 \\
1-percent level & & \\
\hline
\end{tabular}

There was a tendency for a reduction in yields when all the nutrients were applied as foliar rather than as soil applications, but in this instance only the measurement of hands per acre revealed highly significant differences between means.

The omission of both Fe and $\mathrm{Zn}$ from the foliar sprays caused significant reductions in the yield of plantains. A highly significant reduction in number of fruit per acre was measured when $\mathrm{Zn}$ was omitted from the spray, while significant reductions were measured with omissions of $\mathrm{Fe}, \mathrm{B}, \mathrm{Mo}$, and Mn. No significant differences attributable to treatments were measured as to hands per acre obtained. Thus, the effect of the omission of some elements is evident upon the size and number of plantains rather than upon the number of hands. 
As shown in table 4 the results of covariance studies between growth and development criteria (number of leaves, stem circumference, plant height) and plantain yields (weight of bunch, number of fruits, number of hands) indicated significant correlations. However, the correlation coefficients were quite low. Each growth and development criterion, therefore, explained by itself alone, a low fraction of the variation in yields in the experiment.

TABLE 4.-Results of correlation sludies of growth and development crileria on yields of planlains 1

\begin{tabular}{|c|c|c|}
\hline \multicolumn{3}{|c|}{ 5-month-old plants } \\
\hline$x$ & $\boldsymbol{Y}$ & $r$ \\
\hline $\begin{array}{c}\text { Number of leaves } \\
\text { Do. } \\
\text { Do. } \\
\text { Stem circumference } \\
\text { Do. } \\
\text { Do. } \\
\text { Plant height } \\
\text { Do. } \\
\text { Do. }\end{array}$ & $\begin{array}{l}\text { Weight of bunch } \\
\text { Number of fruits } \\
\text { Number of hands } \\
\text { Weight of bunch } \\
\text { Number of fruits } \\
\text { Number of hands } \\
\text { Weight of bunch } \\
\text { Number of fruits } \\
\text { Number of hands }\end{array}$ & $\begin{array}{r}0.233^{* *} \\
.201^{* *} \\
.181^{* *} \\
0.205^{* *} \\
.155^{*} \\
.145^{*} \\
0.246^{* *} \\
.193^{* *} \\
.178^{* *}\end{array}$ \\
\hline \multicolumn{3}{|c|}{ 10-month-old plants } \\
\hline $\begin{array}{l}\text { Stem circumference } \\
\text { Do. } \\
\text { Do. } \\
\text { Plant height } \\
\text { Do. } \\
\text { Do. }\end{array}$ & $\begin{array}{l}\text { Weight of bunch } \\
\text { Number of fruits } \\
\text { Number of hands } \\
\text { Weight of bunch } \\
\text { Number of fruits } \\
\text { Number of hands }\end{array}$ & $\begin{array}{c}0.195^{* *} \\
.152^{* *} \\
.145^{*} \\
0.221^{* *} \\
.179^{* *} \\
.169^{* *}\end{array}$ \\
\hline
\end{tabular}

1 One asterisk indicates significance at the 5-percent level, and 2 asterisks at the 1-percent level.

An overall examination of the data obtained points to the need of fertilization with some of the minor elements for the production of plantains in Lares clay and/or similarly related soils of the Corozal and other regions of similar ecological conditions. The information presented indicates that, under the conditions prevailing where the experiment herein reported was conducted, the application of some of the minor elements is as essential for higher production as that of the well-known major nutrients. It has been shown, furthermore, that the application of these minor elements as foliar sprays at the rate used is not as effective as the application to the soil under 
the aforementioned conditions. The necessity of applying minor elements, particularly $\mathrm{Zn}$ and $\mathrm{Fe}$, is quite clear.

There is a possibility that, in our study, the possible extreme treatment differentials were not reached; thus no sufficiency or, deficiency levels could be established. Perhaps response to a given element might have been possible at higher levels. Caro-Costas, et al. (2) obtained a yield increase when fertilizing plantains with 100 pounds of magnesium in the Orocovis area where Cialitos soils are predominant. In our experiment only 50 pounds were used. Perhaps, a higher level of magnesium might have affected yields. There is currently underway a field experiment at Corozal (on the same Lares clay) to evaluate the effect of magnesium on plantains. Treatments range from 0 to 400 pounds per acre of magnesium.

The potentialities of secondary and minor elements for becoming important items in the fertilization of tropical crops merits further study.

\section{SUMMARY}

Experimental data are presented here on the effect of minor elements and magnesium upon the growth, development, and yield of plantains of the Enano cultivar. The experiment was located on a Lares clay of the Corozal area. The treatments included: 1, Soil applications of complete fertilizer (NPK, minor elements, and magnesium) vs. NPK only and 2, foliar sprays of the same complete fertilizer previously mentioned vs. sprays wherein each one of the elements under study ( $\mathrm{Mg}, \mathrm{Fe}, \mathrm{Mn}, \mathrm{B}, \mathrm{Zn}, \mathrm{Cu}, \mathrm{Mo}$ ) was omitted from the spray solution for a given treatment. Data werc collected as to height of plants and trunk circumference at 5 and 10 months, number of dry leaves and suckers at 5 months, green leaves at 10 months, mean yields (weight), number of fruits, and number of hands per acre.

A study of the data shows that the application of minor elements and magnesium to the soil increased the weight and number of fruit and hands of plantains per acre. Their application also affected the growth and development of the plantain plants as measured by plant height, and number of dry leaves, green leaves, and suckers.

Foliar sprays of nutrients at the rate used were not as effective as soil applications of fertilizers. The omission of $\mathrm{Fe}$ and $\mathrm{Zn}$ from the nutrient sprays caused marked reductions in yields.

\section{RESUMEN}

Aquí se presentan datos experimentales sobre el efecto de los elementos menores y el magnesio en el crecimiento, desarrollo y producción de plátanos de la variedad Enano. El experimento se ubicó en un suelo Lares arcilloso en la región de Corozal. Los tratamientos que se evaluaron fueron los siguientes: 1, Aplicación de un abono completo al suelo (incluyendo NPK, elemen- 
tos menores y magnesio), vs. la aplicación de solamente NPK y 2, aspersiones foliares del abono completo antes mencionado, vs. aspersiones donde se omitieron de la solución cada uno de los elementos bajo estudio ( $\mathrm{Mg}, \mathrm{Fe}$, $\mathrm{Mn}, \mathrm{B}, \mathrm{Zn}, \mathrm{Cu}$ y Mo), dependiendo del tratamiento específico bajo consideración. Se obtuvieron datos sobre la altura de las plantas y la circunferencia del tronco a los $5 \mathrm{y}$ a los 10 meses de edad; número de hojas secas $\mathrm{y}$ de hijos, a los 5 meses; número de hojas verdes, a los 10 meses; rendimiento promedio (peso); $\mathrm{y}$ número de frutas $\mathrm{y}$ de manos de plátanos por cuerda.

El análisis de los datos demuestra que la aplicación de elementos menores y magnesio, cuando el abono se aplicó al suelo, aumentó significativamente los rendimientos, el número de frutas y el número de gajos o manos por cuerda. También, se afectó el crecimiento y desarrollo de los plátanos, según las medidas de altura $\mathrm{y}$ el número de hojas secas $\mathrm{y}$ verdes, $\mathrm{y}$ de hijos.

Las aspersiones foliares con nutrimentos a la concentración usada, no fueron tan efectivas como las aplicaciones del abono al suelo. La omisión de $\mathrm{Fe}$ y $\mathrm{Zn}$ de las soluciones nutritivas indujeron una disminución notable en el rendimiento.

\section{LITERATURE CITED}

1. Bonnet, J. A., Preliminary field test with minor elements on chlorotic symptoms on sugarcane (Unpublished.)

2. Caro-Costas, R., Abruña, F., and Vicente-Chandler, J., Response to fertilization of strip-cultivated plantains growing on a steep latosol in the Humid Mountain Region of Puerto Rico, J. Agr. Univ. P.R. 48 (4): 312-17, 1964.

3. Hernández-Medina, E., Pineapple response to magnesium in Puerto Rico, Proc. Amer. Soc. Hort. Sci. (Caribbean Region) 5: 70-5, 1961.

4. - Response to magnesium of intensively managed sun-grown coffee, J. Agr. Univ. P. R. 62 (8): 185-94, 1968.

5. - Magnesium an important nutrient in pineapple production in a Bayamón sandy clay, J. Agr. Univ. P. R. 48 (1): 17-24, 1964.

6. Hopkins, E. F., Pagán, V., and Ramírez-Silva, F. J., Iron and manganese in relation to plant growth and its importance in Puerto Rico, J. Agr. Univ. P.R. 28 (2): 43-101, 1944.

7. Landrau, Jr., P. and Samuels, G., The effect of fertilizers on the yield and quality of sweetpotatoes, J. Agr. Univ. P.R. 35 (2): 71-87, 1951.

8. - Results of lime and minor-element fertilizer research in Puerto Rico, 1949-55, J. Agr. Univ. P. R. 40 (4): 224-34, 1956.

9. Ramirez-Silva, F. J., The effect of certain micronutrient elements on the growth and yield of pineapple plants, J. Agr. Univ. P.R. $\$ 0$ (4): 197-250, 1946.

10. Schappelle, N. A., The effect of $\mathrm{pH}$ and certain minor elements on the growth of pineapples in water cultures, J. Agr. Univ. P. R. 26 (3): 63-72, 1942. 